\title{
Food Poisoning and Public Health
}

\section{Parkash Meghwar ${ }^{1 *}$, Ahsan Ali Depar ${ }^{1}$, Nizamudin Chaniho ${ }^{1}$ and Heeranand $^{2}$}

${ }^{1}$ Institute of Food Sciences and Technology, Sindh Agriculture University, Tandojam, Sindh, Pakistan

${ }^{2}$ Faculty of Community \& Public Health Sciences, Liaquat University of Medical and Health Sciences Jamshoro Sindh Pakistan
Received: March 23, 2021

Published: April 27, 2021

(C) All rights are reserved by Parkash

Meghwar., et al.

*Corresponding Author: Parkash Meghwar, Institute of Food Sciences and Technology,

Sindh Agriculture University, Tandojam, Sindh, Pakistan.

E-mail: parkashmeghwarifstsau@gmail.com

Globally, with the mushrooming growth of the population, the demand for food commodities is rising worldwide. The furious race of population towards only food without having safety measures from the farm to our homes. The several operations being carried out from farm to fork including harvesting, packing, loading, transportation, unloading, handling, storage, etc. are carried out with complete adherence to Food Safety Laws but if a little mismanagement may lead to contamination with microbes, chemicals, or other environmental particles such as dust, dirt, smoke, etc. Moreover, microbes are present throughout the universe either beneficial to human health or harmful. Even sudden entry of microbes in our food may cause contamination that leads to food poisoning because microbes cannot be visualized easily with naked eye therefore strict hygienic practices should be followed to get rid of from microbial attack on food commodities. Usually, food poisoning can be defined as the clinical syndromes appeared when ingested contaminated food or water with improper handling and processing practices. Common contaminants involved are heavy metals, toxins \& microbes such Virus, bacteria (E. coli, Campylobacter and Salmonella), parasites. The dearth of control over the growing rate of this approachable and curable ailment encounters students of public health \& precautionary medication. Proper handling and storage are the key factors to avoid contamination. Consumption of contaminated food results in some common symptoms like fever, diarrhea, nausea, vomiting, weakness, abdominal pain, cramps, sweating, headache, rashes, etc. that are appeared either in one or two days. Microbes are waiting for the opportunity to enter in food wall at all stages from growing to cooking and eating. So, complete guidelines issued by WHO, FAO, European Union of Food Safety, Pakistan Pure Food Laws, Pakistan Standards for Quality Control Authority, and other concerns should be followed properly. Appropriate sanitation should be taken at every food processing as well as selling unit with well-trained food handlers. Food handlers must be healthy if any worker is sneezing, or coughing may also cause infection. On other hand, food premises are the harbinger of foodborne diseases as compared to our kitchens.

A research study found that about 200 illnesses are produced by risky food. Two million losses occur annually due to contaminated food and drinking water. Unsafe food generates a brutal cycle of sickness and malnutrition, especially young children, infants, the elderly, \& sick and vulnerable people. Moreover, those who are ill are more prone to food poisoning due to weak immune system as microbes in food multiply as quickly as possible. According to the Ministry of Health and Long Term Care, Infectious Diseases Protocol Canada, Food poisoning is not only caused by microorganisms but chemical, heavy metals, and toxins are reported well. Contamination by chemicals results in acute poisoning or sometimes chronic disease e.g. cancer or may cause disability or death. Food poisoning is curable if developed but proper food preparation is significant to us. Nowadays, most of the people are selling food in streets as 
well as roadsides without suitable safety of food commodities. So, community councils should take care to provide guidelines about food handling practices.

It is concluded that to ensure public health, there should be training centers to educate people about the food safety principles to reduce food poisoning outbreaks. As per international food safety experts, there must be food safety programs in the curriculum of educational institutions of every country to aware the population about public health.

\section{Assets from publication with us}

- Prompt Acknowledgement after receiving the article

- Thorough Double blinded peer review

- Rapid Publication

- Issue of Publication Certificate

- High visibility of your Published work

Website: https://www.actascientific.com/

Submit Article: https://www.actascientific.com/submission.php Email us: editor@actascientific.com

Contact us: +919182824667 